\title{
Journal of Surgery and Medicine
}

\section{Original Alvarado scoring system in the diagnosis of acute appendicitis: A cohort study}

\author{
Akut apandisit tanısında orijinal Alvarado skorlama sistemi: Kohort çalışma
}

Yahya Kemal Çalışkan

University of Health Science, Kanuni Sultan Suleyman Research and Education Hospital, General Surgery, Istanbul

\section{Corresponding author / Sorumlu yazar: Yahya Kemal Çalıșkan}

Address / Adres: Sağlık Bilimleri Üniversitesi, Kanuni Sultan Süleyman Eğitim ve Araştırma Hastanesi, Genel Cerrahi kliniği, Küçükçekmece / İstanbul / Türkiye

E-mail: yahyakemalc@yahoo.com

Ethics Committee Approval: Ethics committee approval was not received because the study was performed retrospectively.

Etik Kurul Onayı: Çalışmamız retrospektif olması nedeniyle etik kurul onayı alınmamıştır.

Informed Consent: Informed consent was not received because the study design was retrospective.

Hasta Onamı: Çalışmanın retrospektif olması nedeniyle hasta onamı alınmamıştır.

Conflict of Interest: No conflict of interest was declared by the authors.

Çıar Catıșması: Yazarlar çıar çatıșması bildirmemișlerdir

Financial Disclosure: The authors declared that this study has received no financial support. Finansal Destek: Yazarlar bu çalışma için finansal destek almadıklarını beyan etmişlerdir.

Received / Geliş Tarihi: 06.08.2017 Accepted / Kabul Tarihi: 20.08.2017 Published / Yayın Tarihi: 27.08.2017

\section{Copyright $\odot$ JOSAM}

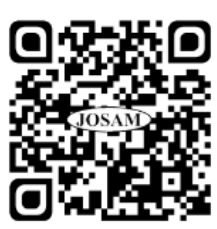

\begin{abstract}
Aims: Although acute appendicitis is the most common cause of acute abdomen, there is still no definitive diagnostic method. Various scores were defined in the literature. In this study, we investigated the effectiveness of the Alvarado score, a clinical scoring system aimed at supporting the diagnosis.

Methods: Patients who were to be operated with acute abdomen and acute appendicitis prediagnosis in our hospital emergency surgery service were calculated before the Alvarado scores. This score has 8 parameters in the system. 1-The right lower quadrant of pain, 2anorexia, 3-nausea-vomiting, 4-right lower quadrant sensitivity, 5-rebound sensitivity, 6-fever, 7-leukocytosis, 8-left shift (granulocytosis). Numbers 4 and 7 are calculated with a total of 10 points, 2 points, 1 point.

Results: Total 200 patients, (128 males, 82 female, male/female: 1.6) mean age was $34.3 \pm$ 15.6, and the age range was 15-78. In ROC analysis, Alvarado scores greater than 6 has demonstrated acute appendicitis diagnosis with $76 \%$ sensitivity and $91 \%$ specificity. Alvarado score of 9-10 showed $100 \%$ sensitivity to detect acute appendicitis.

Conclusions: Clinical scoring systems are frequently used in the diagnosis of acute appendicitis. In publications covering the Alvarado scores of 9-10, the high probability of appendicitis, needs surgical intervention, and advanced examination methods were proposed in scores of 7-8. Our study resulted in consistent with the literature.
\end{abstract}

Keywords: Acute appendicitis, Scoring systems, Alvarado score

Öz

Amaç: Akut apandisit en sık görülen akut karın nedeni olmasına rağmen hala kesin tanı koyduran bir yöntem mevcut değildir. Literatürde çeşitli skorlamalar tanımlanmıştır. Bu çalışmada tanıyı desteklemek amaçlı, bir klinik skorlama sistemi olan Alvarado skorununun etkinliği araştırdık.

Yöntem: Hastanemiz acil cerrahi servisinde akut karın ve akut apandisit ön tanısı ile ameliyat edilecek hastalara, ameliyat öncesinde Alvarado skorları hesaplandı. Bu skor sistem içerisinde 8 parametre bulunmaktadır. 1-Ağrının sağ alt kadrana göçü, 2-İştahsızlık, 3-Bulantı-kusma, 4Sağ alt kadranda hassasiyet, 5-Rebound hassasiyet, 6-Ateş, 7-Lökositoz, 8-Sola kayma (granülositoz). 4 ve 7 numara 2 puan diğerleri 1 puan olmak üzere toplam 10 puan üzerinden hesaplanır.

Bulgular: Toplam 200 hasta, (118 erkek, 82 bayan, erkek/bayan:1.4) ortalama yaş 34.3 \pm 15.6 , yaş aralığının 15-78 olduğu görüldü. ROC analizinde 6'nın üzerindeki Alvarado skorlarının $\% 76$ sensitivite, \%91 spesifisite ile akut apandisit tanısını gösterebileceği saptandı. Alvarado skoru 9-10\%100 sensitivite ile akut apandisiti tespit etti.

Sonuçlar: Akut apandisit tanısında klinik skorlama sistemleri sık kullanılmaktadır. Alvarado skorlama sistemini kapsayan yayınlarda 9-10 arası yüksek ihtimal apandisit (cerrahi girişim), 7 8 arası değerler için ileri tetkik yöntemleri önerilmiştir. Çalışmamızda literatürle uyumlu sonuçlanmıştır.

Anahtar kelimeler: Akut apandisit, Skorlama sistemleri, Alvarado skoru. 


\section{Introduction}

Acute appendicitis is one of the most urgent surgical conditions. Acute appendicitis is sometimes delayed due to very different complaints, and sometimes it is confused with other illnesses showing classic complaints leading to the patients being operated with unnecessary or misdiagnosis. Delay in the diagnosis of acute appendicitis increases the likelihood of perforation. Perforation increases the risk of morbidity and mortality of the disease and therefore many cases suspicious for acute appendicitis are taken without delay very soon. Thus, the probability of encountering a disease-free appendix vermiformis during surgery, which we call negative laparotomy, is reported in $13-36 \%$ [1-4]. These rates, which are considered as high, should be absolutely reduced by the fact that the negative laparotomy is not as low as the morbidity. The group with the highest morbidity is the complicated appendicitis. The most important factor is the delay with the cause of patient-induced or poor diagnosis. The rate of complicated appendicitis detection during surgery has been reported between 12 and $21 \%$ [1,4,5]. Negative appendectomies and complicated appendicitis rates, which are considered to be high rates, have brought out auxiliary imaging methods in the diagnosis and the investigation of the location with ultrasonography and tomography in the diagnosis of appendicitis has begun. The evaluation of appendicitis by ultrasonography was first made at the beginning of the 1980's and published as a case report [3].

Alvarado score is one of the clinical scoring systems used in the diagnosis of appendicitis, as a noninvasive method, easy and affordable. It was first introduced in 1986 and developed mainly for pregnant females. Actually sensitivity of score can be low in female patients, such as ruptured heterotopic pregnancy might cause acute abdomen condition mimicking acute appendicitis. Later it has been validated in all population. Still the Alvarado score is in use in in the diagnosis of appendicitis [6-8]. We aimed to measure the efficacy of Alvarado score in diagnosis of acute appendicitis.

\section{Material and methods}

Descriptive (prospective cohort) study is designed, and the universal principles of the 1964 Declaration of Helsinki and its later amendments were applied. This research was conducted according to the principles of the World Medical Association Declaration of Helsinki "Ethical Principles for Medical Research Involving Human Subjects".

The patients who operated with appendectomy for acute appendicitis are enrolled into the study. Alvarado score was calculated. The score has six clinical and two laboratory items with a maximum value of 10 points (Table 1). Demographic status, history, laboratory, operation and pathology records were retrieved from patients' files. Sample size was chosen as 187 patients to predict the determination of the difference with a confidence level of $90 \%$ and margin error of $6 \%$. In statistical assessments, 13 patients were added to reduce the margin of error and the final sample size was determined as 200 .

Statistical calculations were performed using IBM SPSS 22 (IBM SPSS, USA). Variables are expressed as mean \pm standard deviations (SD) or as medians (range) depending on their distribution. Categorical variables were expressed as frequencies and percentages. The Chi-square and Fisher's exact tests were used for comparison of continuous parametric variables. Normality was assessed by means of the KolmogorovSmirnov test. The t-test was used for comparison of parametric variables with normal distribution. Pathological examination with acute appendicitis was used as determinant factor. Sensitivity and specificity of certain Alvarado score groups (0-4, 5-6, 7-8, 9-10) are calculated. ROC curve analysis is performed to reveal custom advisable Alvarado score level. The statistical results were presented with a $95 \%$ confidence interval (CI). The differences were considered statistically significant if the p-value was less than 0.05 .

Table 1: Alvarado Score

\begin{tabular}{|c|c|}
\hline Symptoms & Points \\
\hline Abdominal pain that migrates to the right iliac fossa & 1 \\
\hline Anorexia (loss of appetite) or ketones in the urine & 1 \\
\hline Nausea or vomiting & 1 \\
\hline Tenderness in the right iliac fossa & 2 \\
\hline \multicolumn{2}{|l|}{ Signs } \\
\hline Rebound tenderness & 1 \\
\hline Fever of $37.3{ }^{\circ} \mathrm{C}$ or more & 1 \\
\hline \multicolumn{2}{|l|}{ Laboratory } \\
\hline Leukocytosis $>10,000 / \mathrm{mm} 3$ & 2 \\
\hline Neutrophilia $>70 \%$ & 1 \\
\hline Total & 10 \\
\hline
\end{tabular}

\section{Results}

Two-hundred cases enrolled into study. ROC analysis resulted strong area under curve value (AUC:0.921) (Figure 1, Table 2). This ROC analysis showed that Alvarado score greater than 6 shows acute appendicitis at a sensitivity of $76 \%$ and a specificity of $91 \%$. In second stage of analysis, Alvarado score groups $(0-4,5-6,7-8,9-10)$ are formed. No statistical difference was determined between demographics of patients and groups ( $>0.05$ ). Alvarado score groups statistics is shown in table 3. Score of 5-6 showed $71.4 \%$ sensitivity to determine acute appendicitis, Score of 7-8 showed 97.3\%, and 9-10 showed $100 \%$ sensitivity.

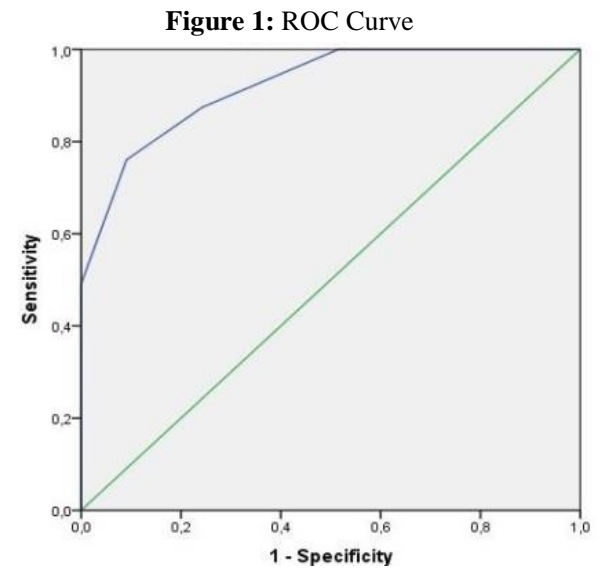


Table 2: ROC analysis

\begin{tabular}{lllllc}
\hline & \multirow{2}{*}{$\begin{array}{l}\text { Std. } \\
\text { Area }\end{array}$} & $\mathrm{p}$ & \multicolumn{3}{c}{$\begin{array}{c}\text { Asymptotic 95\% Confidence } \\
\text { Enterval }\end{array}$} \\
\cline { 3 - 6 } & & & \multicolumn{2}{c}{ Lower Bound } & Upper Bound \\
\hline 0.921 & 0.023 & 0.0001 & 0.876 & 0.966 \\
\hline \multicolumn{5}{c}{ Table 3: Alvarado score groups statistics } \\
\hline Alvarado Score & $0-4$ & $5-6$ & $7-8$ & $9-10$ \\
\hline n & 14 & 56 & 113 & 17 \\
Appendicitis & 0 & 40 & 110 & 17 \\
No appendicitis & 14 & 16 & 3 & 0 \\
p & 0.0001 & 0.005 & 0.001 & 0.040 \\
Sensitivity & 0 & 71.4 & 97.3 & 100 \\
Specificity & 10.2 & 11.8 & 34.5 & 18.0 \\
\hline
\end{tabular}

${ }^{1}$ Fisher's exact test

\section{Discussion}

Assessment of suspected appendicitis patients is driven to identify all patients with acute appendicitis early in the clinical course, with the lowest incidence of therapeutic laparoscopy. The unanswered diagnosis of appendicitis may result in severe, negative patient outcomes, especially perforated, while nontherapeutic operations are subject to surgical morbidity without treating the underlying condition. Data on history, physical exams and laboratory tests are used to describe the clinical probability of acute appendicitis. Those with a low sobering score are assessed for the evaluation of alternative diagnoses. Those with a higher uptake score are used to improve the details of imaging and Surgical Laparoscopic search evaluation and to minimize the possibility of a negative abdomen [1-4].

Although appendicitis is the most common emergency surgery, accurate and timely diagnosis is sometimes difficult. For this reason, unnecessary or late operations are problems we encounter in patients with suspected acute appendicitis. To make a correct and timely diagnosis, at least to the doctor it is extremely useful in terms of patients who are referred early. Obviously, evaluating patients with clinical and laboratory results alone is not enough. Just it has been diagnosed by this method and it has been reported that the patients who underwent operation were operated on 10-13\% of unnecessary cases even in the best series and complicated appendicitis was encountered between $11 \%$ and $20 \%$ [1, 5]. With imaging methods it is predicted that these ratios could be lowered further. Thus, accurate and timely diagnostic imaging of ultrasound and tomography has been researched and discussed in many publications [1-5]. In a meta-analysis of fourteen publications, $80 \%$ sensitivity and $81 \%$ selectivity of ultrasonography as a diagnostic tool were demonstrated and the utility of detecting appendicitis was demonstrated [9]. However, studies showing high sensitivity for acute appendicitis with $91 \%$ sensitivity and $95.9 \%$ selectivity have also been reported [10]. In this respect, it is possible to identify in the literature the opposite views. Imaging methods have been shown to delay the diagnosis of acute appendicitis due to their low sensitivity $[4,11]$.

The Alvarado score is a scoring system which can be used determine the patients with acute appendicitis with very low likelihood. This score can distinguishes them from acute appendicitis according to other causes of abdominal pain.
Patients with not very high Alvarado scores should be evaluated further with pre-treatment imaging. While various scoring systems are proposed to standardize clinical and laboratory evaluation for acute appendicitis, recently the modified Alvarado score is the most commonly used score $[12,13]$. In our study, we used original Alvarado score. Main rational for this issue, we want to determine our results with original Alvarado score.

The two most important factors, tenderness in the right lower quadrant and leukocytosis, are assigned two points, and remaining parameters are assigned one point each, for a possible total score of ten points. The original Alvarado score may result with a possible total of 10 points, but those medical facilities that are unable to perform a differential white blood cell count. Modified Alvarado Score with a total of 9 points might not be accurate as the original score. The high diagnostic value of the original Alvarado score has been confirmed in a number of studies across the world. The consensus is that the Alvarado score is a noninvasive, safe, diagnostic method. Also Alvarado is simple, reliable and repeatable, and able to guide the clinician in the management of the case $[6,7,11]$. A score of 5 or 6 is compatible with suspicion of the diagnosis of acute appendicitis. A score of 7 or 8 indicates a probable appendicitis, and a score of 9 or 10 indicates a very probable acute appendicitis $[6,7]$.

Although clinical judgement is very important in diagnosing acute appendicitis, some scoring system have offered to increase sensitivity of final diagnose $[6,14]$. In our study, we found that high sensitivity but low specificity in Alvarado score greater than 8 . ROC analysis resulted 6 and more score with high sensitivity and specificity.

Main limitation of this study is study design. Some conclusions have to be made with comparative studies. Future studies are needed to compare original and modified Alvarado score efficacy on diagnose of acute appendicitis.

In conclusion, original Alvarado score is still useful to take decision in patient diagnose and in choosing relevant treatment.

\section{References}

1. Peterson MC, Holbrook JH, Hales D, Smith, NL, Staker, LV. Contributions of history, physical examination and laboratory investigations in making medical diagnosis. West $\mathrm{J}$ Med 1992;156:163-5.

2. Anderson RE, Hugander A, Thulin AJ. Diagnostic accuracy and perforation rate in appendicitis: Association with age and sex of the patient and with appendectomy rate. Eur J Surg 1992; 158: 37 41.

3. John H, Mathiessen FK, Neckelmann K, Hovendal CP, Bellstorm T, Gottrup F. Comparison of clinic judgment and diagnostic ultrasonography in the diagnosis of acute appendicitis experience with a score-aided diagnosis. Eur J Surg 1997;163:433-443.

4. Steven LL, Alicia JW, Hung SH. Computed tomography and ultrasonography do not improve and may delay the diagnosis and treatment of acute appendicitis. Arch Surg 2001;136: 556-562.

5. Colson M, Skinner KA, Dunnignton G. High negative appendectomy rates are no longer acceptable. Am J Surg 1997;174:723-6.

6. Alvarado A. A practical score for the early diagnosis of acute appendicitis. Ann Emerg Med 1986 May;15(5):557-64.

7. Augustin G, Majerovic M. Non-obstetrical acute abdomen during pregnancy. Eur J Obstet Gynecol Reprod Biol 2007;131:4-12.

8. Selçuk S. Ruptured heterotopic pregnancy: Case report. J Surg Med. 2017;1:15-17. 
9. Terasawa T, Blackmore CC, Bent S, Kohlwes RJ. Systematic review: Computed tomography and ultrasonography to detect acute appendicitis in adults and adolescents. Ann Intern Med 2004; 141: 537-546.

10. Vidmar D, Omejc M, Cerar A, Makiar J, Repse S. Influence of ultrasonography on clinical decision making in suspected acute appendicitis in adults. Eur Surg 2006; 38: 445-450.

11. Maroju NK, Robinson Smile S, Sistla SC, Narasimhan R, Sahai A. Delay in surgery for acute appendicitis. ANZ J Surg 2004;74:773-6.

12. Rastović P, Trninić Z, Galić G, Brekalo Z, Lesko J, Pavlović M. Accuracy of Modified Alvarado Score, Eskelinen Score and Ohmann Score in Diagnosing Acute Appendicitis. Psychiatr Danub 2017;29:134-141.

13. Singla A, Singla S, Singh M, Singla D. A comparison between modified Alvarado score and RIPASA score in the diagnosis of acute appendicitis. Updates Surg 2016;68:351-355.

14. Bergeron E. Clinical judgement remains of great value in the diagnosis of acute appendicitis. J Can Chir 2006;49:96-100. 